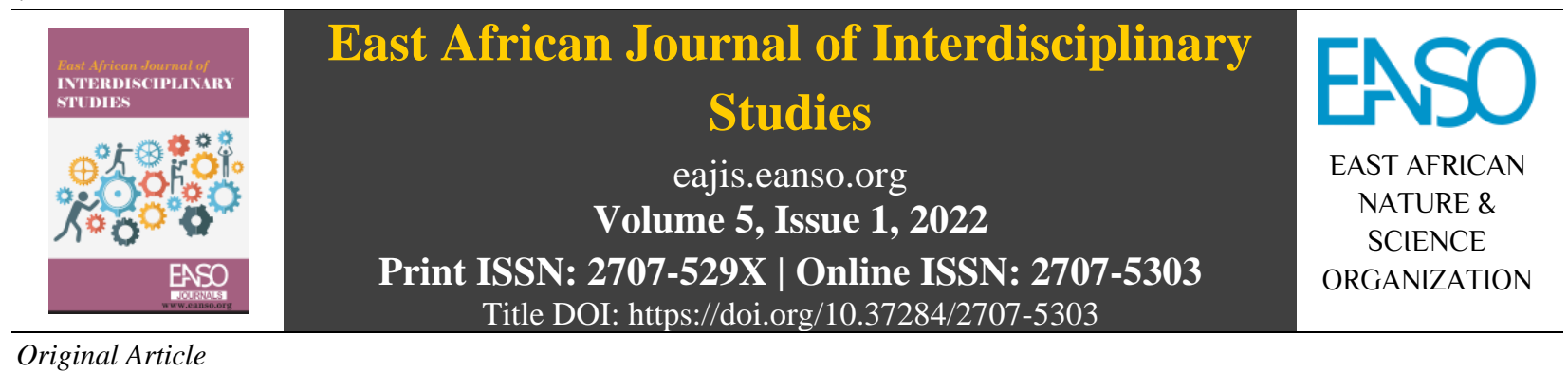

\title{
Instructional Material Provision and Performance of Upgraded National Schools in Western Kenya.
}

\author{
Violet Wekesa, ${ }^{1 *} \&$ Prof. Kisilu Kitainge, $P h D^{1}$ \\ ${ }^{1}$ University of Eldoret, Kenya; P. O. Box 1125 - 30100, Eldoret. \\ * Author for Correspondence ORCID ID: https://orcid.org/0000-0002-7780-6980; Email: violetwekesa37@gmail.com
}

Article DOI: https://doi.org/10.37284/eajis.5.1.565

\section{Date Published: ABSTRACT}

01 March 2022 The performance of upgraded extra county schools to national status in Kenya continues to attract key stakeholders when the time the KCSE results are being

Keywords: announced. This is because despite their upgrading, the performance of these upgraded new schools continues to worry stakeholders. This paper investigates how

Instructional, the planning for instructional resources influences academic performance. A Resource, descriptive survey research design was used with the target population consisting of 8 principals and 295 teachers from 8 upgraded extra county schools to national status Planning, in Western Kenya. A sample of 170 teachers was selected through simple random Dynamics, technique to be involved in the study. The instruments used to collect data consisted

Performance, of questionnaire and interview schedule. Data analysis has been performed using Upgraded. quantitative and qualitative forms. Quantitative analysis of data has been facilitated by use of descriptive and inferential statistics with the help of Statistical Product and Service Solutions (SPSS Version 25.0). The study found that aside many instructional materials required in schools, only text-books for students were supplied in adequate quantity. However, learning resources for teachers (including reference books) were not adequately provided to these schools. In line with the government agenda of promoting ICT knowledge, the study discovered that ICT resources like computers were not adequately provided after the Extra County Schools in the region were upgraded to national status in Western Kenya. Correlation statistics showed that there existed no significant relationship $(\mathrm{p}>0.05)$ between instructional material planning dynamics and performance of Extra County Schools after they were upgraded in Western Kenya. The paper recommends that there is need for schools to consider adoption of new instructional media in teaching and learning.

\section{APA CITATION}

Wekesa, V., \& Kitainge, K. (2022). Instructional Material Provision and Performance of Upgraded National Schools in Western Kenya East African Journal of Interdisciplinary Studies, 5(1), 30-39. https://doi.org/10.37284/eajis.5.1.565.

\section{CHICAGO CITATION}

Wekesa, Violet, and Kisilu Kitainge. 2022. "Instructional Material Provision and Performance of Upgraded National Schools in Western Kenya". East African Journal of Interdisciplinary Studies 5 (1), 30-39. https://doi.org/10.37284/eajis.5.1.565.

30| This work is licensed under a Creative Commons Attribution 4.0 International License. 
East African Journal of Interdisciplinary Studies, Volume 5, Issue 1, 2022

Article DOI: https://doi.org/10.37284/eajis.5.1.565

HARVARD CITATION

Wekesa, V., \& Kitainge, K. (2022) “Instructional Material Provision and Performance of Upgraded National Schools in Western Kenya”, East African Journal of Interdisciplinary Studies, 5(1), pp. 30-39. doi: 10.37284/eajis.5.1.565.

\section{IEEE CITATION}

V. Wekesa, \& K. Kitainge, "Instructional Material Provision and Performance of Upgraded National Schools in Western Kenya”, EAJIS, vol. 5, no. 1, pp. 30-39, Mar. 2022.

\section{MLA CITATION}

Wekesa, Violet, and Kisilu Kitainge. "Instructional Material Provision and Performance of Upgraded National Schools in Western Kenya". East African Journal of Interdisciplinary Studies, Vol. 5, no. 1, Mar. 2022, pp. 30-39, doi:10.37284/eajis.5.1.565.

\section{INTRODUCTION}

Instructional materials consist of material and nonmaterial audio and audio-visual materials present in school to facilitate school management and improve the classroom learning (Yunusa, 2016). Bausch and Ault (2008) defined instructional materials as resources which provide support, or help in the process of teaching and learning. Mugure (2012) said that they are inputs of education which are significant to teaching of curriculum subjects in secondary schools. Bausch and Ault (2008) said that instructional learning resources are items which support and aid in the process of teaching and learning in secondary schools. The performance of student is dependent on the planning and management of instructional materials in the school by management (Ayoti, Koteng'\& Ongunya, 2016). Hence, the instructional materials availability and utilisation is an important element of general planning and administration of schools. This means that instructional learning resources support and aid in the teaching and learning process in schools and the upgraded extra county schools to national status need to plan to avail them to ensure that quality learning takes place. The resources played a significant role in the realisation of the educational objectives and goals through meeting the physical requirements of students and teachers (Abayomi \& Olukayode, 2006).

Lasoi et al. (2017) indicated that planning management of instructional materials necessitates the achievements of quality education in secondary schools. Board of Management and administrators use different strategies of administration to monitor the use of school resources in enhancing teaching and learning in schools. The school administrators plan and manage the physical resources and teachers in order to make sure that there is effectual learning in classrooms. Every school has a task of monitoring teaching and learning to ensure the quality of instructional materials provided used in promoting the teaching and learning of students in schools (Andiema, 2020). Improvements in science and technology demands that school board of management incorporate proper measures of resource administration so that to enhance the quality of instructional process. A positive correlation exists between quality of instructional learning resources, teaching staff, and performance in academics as Ayoti et al. (2016) found that efficient management of instructional materials produces positive academic outputs. Instructional material planning determines the rate of attainment of educational goals in educational institutions. Instructional material availability and utilisation is significant to general instructional management process in the schools. The progress of schools is measured on how it is providing the required instructional materials to ensure effective and efficient teaching and learning process happens (Bausch \& Ault, 2008).

Student learning performance in classroom is mainly dependent on the presence of proper instructional materials because acquisition of relevant skills is dependent on the quality of learning resources used. The academic performance of student is determined by appropriate planning and management strategies of instructional materials (Ayoti et al., 2016). Investment in instructional learning resources is pivotal to ensure that classroom becomes avenues where students work together, share knowledge from one another and benefit from school environment that is supportive; this ensures that student learning happens and all learners achieve their full academic potentials (Mugure, 2012). Mwili et al. (2015) argue that instruction learning items are significant factors

31| This work is licensed under a Creative Commons Attribution 4.0 International License. 
when implementing a curriculum in secondary schools. They assist teachers to achieve their instructional goals and provide directions to the teaching and learning process, which result to realisation of improved academic performance by students.

With the government being committed to ensure that equity in education access for students across the country to access national schools, they upgraded the extra county schools to national status from the year 2011. However, the upgrading did not match with the resource provision hence affecting the provision of quality education. However, research show that despite the upgrading of new extra county schools to national level, past research has shown that some are struggling in performance.

\section{Problem Statement}

Instructional materials are key inputs towards ensuring teaching and learning activities are properly conducted in schools. With the upgrading of the extra county schools to national status in Western Kenya, it was expected that this would go hand in hand with increased provision of instructional materials. The planning for provision of adequate instructional materials to ensure learning takes place with the admission of new students is a key role that needs to be performed by the school management. However, the extent to which school management have planned to ensure the right and adequate instructional materials are provided for curriculum implementation has not been adequately researched. Furthermore, the relationship between instructional materials dynamics and performance of these upgraded national schools has not been studied necessitating this study.

\section{LITERATURE REVIEW}

Ayoti et al. (2016) observed that learners' academic performance in secondary schools was mainly dependent on availability and appropriateness utilisation of instructional learning materials since learners were able to acquire necessary competencies when they were used by teachers in schools. However, research findings showed that there were inadequate instructional materials in many secondary schools in most sub-Saharan
African nations (UNICEF, 2016). This state is not different in Kenya because past studies have shown evidence of schools suffering as a result of inadequacy of instructional learning resources (Mabeya, Gikuhi \& Anyona, 2019). Unless secondary schools are properly provided with these resources, efficient teaching and learning could not happen which may ultimately affect performance. In Nigeria's Ekiti State, Olayinka (2016) researched on the influence of instructional materials to secondary school students' academic performance in social studies subject. The study found that there existed significant difference between pre-test and post-test of learners who were in the experimental category. It was also discovered the sex was not a significant predictor of academic performance in social study. The research concluded that learners taught using instructional materials fared better in academic compared to those that were taught without these resources. This means that adequate planning and provision of instructional materials is key towards improving student academic performance in social studies.

In Tanzania, Tety (2016) looked at the degree in which a sample of Rombo district secondary schools utilised quality and adequate instructional materials in class and how this usage affected students' academic performance. It was found that learning resources was pivotal to teachers' instructional delivery and student academic achievement. Further, most schools under the community management in the area did experience shortage in necessary instructional teaching and learning resources. Moreover, the study indicated that teachers utilised various measures to ensure there was quality instruction in class by borrowing books. Olatunde and Omondi (2010) examined teaching and learning resources effect on academic performance of students in Mathematics in Siaya County. They discovered that planning for and use of teaching and learning materials by board of management affected students' academic achievement in Mathematics in the study area. The gap created from Olatunde and Omondi (2010) investigation is due to the fact that it was done in mixed schools whereas this investigation focuses in upgraded National Schools to establish how planning for resource provision affected performance of the institutions in various areas not only academic performance.

32 This work is licensed under a Creative Commons Attribution 4.0 International License. 
Akungu (2014) explored learning materials influence of on students' performance in KCSE examinations in secondary schools within Embakasi Sub County, Nairobi County. Akungu (2014) found that instructional learning resources were available and they were used in the classroom learning and consisted of chalks, charts, and dusters. Nevertheless, Akungu (2014) found that despite provision of instructional materials, the increased enrolment of students in Embakasi Sub County public secondary schools overstretched materials available hence affecting quality secondary education delivery. The research by Akungu (2014) focused on performance in KCSE while this study goes further to capture other aspects of institutional performance in upgraded National Schools. Mwili et al. (2015) investigated instructional learning materials influence on academic achievement of students in Makueni County public secondary schools. The study discovered that the performance of student was dependent on availability and use of laboratory apparatus, laboratory chemicals, classrooms, chalks, chalkboard, charts, text-books, course books, student guides, and teachers' reference books among other learning materials by teachers in classroom. The gap created in this study is that it was conducted in Makueni County (Eastern Kenya) while this one concentrated on Western Kenyan Counties to establish how planning for the instructional materials influenced performance of elevated national secondary schools in Western Kenya.

Bosibori et al. (2015) sought to establish whether presence of instructional learning materials affected inclusive education implementation among Nyamira North Sub County pre-school centres. Findings showed that teaching and learning materials were not adequate in the pre-school centres. Further, $78.0 \%$ of teachers said that the situation of inadequacy of instructional materials affected inclusive education preparedness. The gap created in this study is that it involved pre-school centres whereas this one is in public secondary schools. Omego and Simatwa (2015) analysed instructional materials based on problems encountered by Headteachers in improving Kisumu East Sub County public secondary school students' academic achievement. They found that school heads experienced inadequacy of instructional materials $(53.6 \%)$. The gap created from Omego and Simatwa (2015) is that they did not link instructional material materials and academic performance through use of advanced statistical tests which the study endeavoured to examine.

Livumbaze and Achoka (2017) research was to examine the influence of learning materials on Hamisi Sub County public secondary schools students' academic performance. The result revealed that learners recorded dismal performance in academics because of inadequate planning and provision of instructional learning resources in their schools. This study departs from Livumbaze and Achoka focus by looking at the institutional performance in a wider perspective rather than on academic achievement alone. Njagi (2018) assessed the factors that affected the quality of education provision in newly started secondary schools in Mathira Sub County, Nyeri County. Findings revealed that newly established schools lacked the necessary infrastructure for provision of quality education. Njagi (2018) also established that the many newly established schools did not have adequate resources, were highly understaffed and admitted learners with low entry behaviour thereby compromising the provision of quality education. Further, the study found that books were inadequate and that classrooms were not enough to allow proper learning to take place. The study departs from Njagi (2018) focus by conducting research among existing secondary schools that were upgraded to national status in Western Kenya. The present study investigated whether newly upgraded secondary schools to national status had planned for new instructional materials dynamics for the aim of improving performance of schools in Western Kenya.

\section{MATERIALS AND METHODS}

The study was conducted in four Western Kenya Counties of Vihiga, Bungoma, Kakamega and Busia. There are eight upgraded national schools with an estimated student population of 5600 and 270 members of the teaching staff by the year 2019 . The study used mixed method research paradigm with a descriptive survey research design. The eight upgraded extra county schools to national level were; Lugulu Girls, Bunyore Girls, Friends School 
Kamusinga, Butula Boys, Kakamega Boys, Butere Girls, Kolanya Girls, and Chavakali Boys. The target population consisted of 8 principals and 295 teachers. The sample size involved 170 teachers and 8 principals who were selected through systematic sampling and purposive sampling methods. Questionnaires, interview schedule, and document analysis were used to collect data. Quantitative data will be coded, entered, and analysed with the help of SPSS Version 25.0 computer software. Analysis of data was done using frequencies, percentages, means and standard deviation. Karl Pearson correlation was used to determine the relationship between instructional resource materials provision and institutional performance. Qualitative data was analysed using thematic content analysis.

\section{RESULTS AND DISCUSSIONS}

The objective of the study was to investigate how instructional material dynamics were conducted at the upgraded schools in the Western region of the country and their influence on performance. The teachers were asked to indicate the degree to which instructional dynamics had been done in their institutions. Their responses are presented thus in Table 1. 


\section{Table 1: Instructional material Dynamics in Upgraded National Schools}

\section{Adequacy}

Text books were increased to aid in student

learning after upgrade

Learning resources were provided and they are

adequate to assist teachers in classroom instruction after upgrade

Instructional process was effectively implemented and conducted by all concerned to ensure curriculum goals are achieved after upgrade

Stationery resources are in plenty and adequate after upgrading to ensure that quality education is provided in school

Computers are available and adequate in our school to ensure that teachers and students acquire ICT knowledge after upgrade

Composite values

\section{SD \\ D}

18 (11.4)

$34(21.5)$

$48(30.4)$

$28(17.7)$

$58(36.7)$
$10(6.3)$

$68(43.0)$

$50(31.6)$

$66(41.8)$

$62(39.2)$
$10(6.3)$

UD

$16(10.1)$

$30(19.0)$

26 (16.5)

$14(8.9)$
A

82 (51.9)

SA

$32(20.3)$

18 (11.4)

8 (5.1)

2.35

1.095

Key: $S D=$ Strongly Disagree, $D=$ Disagree, $U D=$ Undecided, $A=$ Agree, $S A=$ Strongly Agree, $M=$ Means and $S D=$ Standard Deviation; $f$ (\%) 
The research data in Table 1 show that $82(51.9 \%)$ of teachers agreed and $32(20.3 \%)$ strongly agreed that text-books ratio was increased after the upgrade to assist in students learning. This show that majority of teachers agreed with the statement $(M=$ 3.63, $S D=1.20)$. Considering there was increased in enrolment on these schools, textbook ratio had to be standardised and therefore appropriate plans and measures had to be put in place to ensure the required books are availed on time and adequately. The outcome is supported by study observation and interview with the principals who said that the current text-books ratio was 1:1 in compulsory subjects. One Principal No. 1 had this to say with regard to textbook ratio:

Fair, with text-books but not other things like learning resources (Principal 1, personal interview, July 1, 2019)

Another (No. 2) Principal remarked that:

The text-books ratio is currently 1:1, white boards and marker pens are adequate. One digital screen (smart board) is adequate (Principal 2, personal interview, July 1, 2019).

This shows that efforts have been made to avail the required text-books in schools. However, in terms of student book ratio for non-compulsory subjects, the ratio was 1:5. These non-compulsory subjects consisted of Agriculture, Home Science, Music, and Woodwork. Different from the study findings, Omego and Simatwa (2015) established that only $4(13.3 \%)$ of the schools had well equipped libraries, the rest had some sought of book stores with very few relevant books for reference most of which were irrelevant foreign donations. In addition, Mwili et al. (2015) found that both Headteachers and teachers agreed that most of public secondary schools had inadequate text-books for students and this negatively affected the outcome in KCSE examinations.

When asked on whether learning resources for teachers were increased, $68(43.0 \%)$ of respondents disagreed and $34(21.5 \%)$ strongly disagreed. This means that most school did not receive additional learning resources $(M=2.35, S D=1.09)$ hence providing less assistance to teachers during classroom instruction. When learning resources are inadequate, it may affect the delivery of curriculum content in classrooms hence affecting students' performance in the subject. In support of teachers' responses, the study observation revealed that schools had very few learning resources compared to the student population hence influencing institutional performance. The study agrees with findings of Mwili et al. (2015) research in Makueni County that established that $78.0 \%$ of respondents agreed that reference books and guides were inadequate in most secondary schools. This state of inadequacy of reference guides affected academic performance of schools.

Thirdly, 50 (31.6\%) of teachers disagreed with the notion that instructional process was effectively implemented and conducted by all officials concerned to ensure curriculum goals were attained after upgrade. Descriptive data also show that majority of teachers disagreed with the statement $(M=2.30, S D=1.14)$. This means that there existed instructional leadership gaps after the eight schools were upgraded and, in most cases, teachers were left on their own to plan and organise how curriculum goals with the acquired goals were going to be realised.

On provision of stationery to support curriculum work after upgrade, $66(41.0 \%)$ of respondents disagreed that these materials were provided and only $34(21.5 \%)$ agreed that they were provided with those resources. Mean statistics reveal that the provision of stationery and other materials attached to them were moderately $(M=2.69, S D=1.32)$ provided to schools. This implies that despite some schools receiving stationery, they were not adequate to cater for the increased instructional needs in public secondary schools in the region. With regard to provision of current and modern information technological resources like computers after the upgrade, $58(36.7 \%)$ of respondents strongly disagreed and only $16(10.1 \%)$ said they were provided with. This implies that computers and other ICT resources were not adequately provided $(M=2.07, S D=1.14)$ in schools to help in students acquisition of ICT knowledge in schools. This agrees with Livumbaze and Achoka (2017) who found that only $1(8.3 \%)$ school had ICT (Internet / Intranet connection) and infrastructure. This meant that majority (91.7\%) of the schools lacked ICT infrastructure. This show that the situation of

36| This work is licensed under a Creative Commons Attribution 4.0 International License. 
inadequacy is not only in upgraded schools but across all the spectrum of schools in the country.

To those schools that had ICT infrastructure, the computers could not serve the whole student population well. Average values show that teachers were undecided $(M=2.61, S D=1.18)$ meaning that some were provided with additional instructional

Table 2: Instructional material provision and Institutional Performance

\begin{tabular}{|c|c|c|c|}
\hline & & $\begin{array}{l}\text { Instructional materials } \\
\text { dynamics }\end{array}$ & $\begin{array}{l}\text { Performance } \\
\text { after }\end{array}$ \\
\hline \multirow{3}{*}{$\begin{array}{l}\text { Instructional } \\
\text { dynamics }\end{array}$} & Pearson Correlation & 1 & .074 \\
\hline & Sig. (2-tailed) & & .357 \\
\hline & $\mathrm{N}$ & 158 & 158 \\
\hline \multirow[t]{3}{*}{ Performance after } & Pearson Correlation & .074 & 1 \\
\hline & Sig. (2-tailed) & .357 & \\
\hline & $\mathrm{N}$ & 158 & 158 \\
\hline
\end{tabular}

The correlation statistics (Table 2) show that there exists no significant relationship between instructional materials dynamics and performance of upgraded National Schools in the Western region of Kenya. Therefore, the first null hypothesis was accepted ( $p>0.05)$ leading to the conclusion that there exists no significant relationship between instructional material dynamics and performance of upgraded schools to national level in Western Kenya. Hence, even after upgraded of extra county schools to national status, these institutions do not have adequate instructional materials thereby having little or no effect on institutional performance. The findings of this study concur with those of Mwili et al. (2015) that showed that availability of teachers' reference books and guides was not associated with student's academic performance. Specifically, schools that recorded better performance had adequate instructional materials compared to schools that did not have. Nevertheless, results were encouraging (positive correlation) suggesting that if instructional materials were provided in adequacy, institutional performance would increase significantly.

\section{CONCLUSIONS AND RECOMMENDATIONS}

The study found that with increased enrolment in the upgraded schools, the instructional learning materials (reference notes, lesson guides, and materials while others did not receive the instructional materials in adequate.

The Karl Pearson correlation coefficient was computed at $95.0 \%$ significant level to check on relationship between instructional materials provision and performance of upgraded extra county schools to national status in western Kenya. The results are as shown in Table 2. stationery) were not adequately provided for to ensure quality education was provided. The upgraded national schools had made significant progress in providing adequate text-books for students but felled short of providing learning resources for teachers. The lack of planning initiatives for provision of learning resources affected teaching learning process hence the drop in performance in KCSE examinations from the presented in chapter four. Nevertheless, the computed correlation statistics is promising since planning and provision of adequate instructional learning materials by government, school administration, and parents would result to improvement in institutional performance. There is need for schools to consider adoption of new instructional media in teaching and learning. Focus of acquiring print media resources would not match the current global standards where it is expected that the learners are technological literate. In addition, the plan by the government through the Ministry of Education to provide text-books to schools should be enhanced to ensure they reach the target students on time. This will enhance effective curriculum process. Teachers need also to update themselves on technological knowledge on how to operate the new media devices in teaching.

37| This work is licensed under a Creative Commons Attribution 4.0 International License. 


\section{REFERENCES}

Abayomi, A. \& Olukayode, M. (2006). Effects of cooperative and competitive learning strategies on students' performance in Mathematics. The Nigerian Journal of Guidance and Counselling, 11(1), 60-69, Ilorin Nigeria.

Akungu, J. A. (2014). Influence of teaching and learning resources on students' performance in Kenya certificate of secondary education in free day secondary education in Embakasi district, Kenya (Doctoral dissertation, University of Nairobi).

Andiema, N.C. (2020). Teachers' competency in evaluation of competency based curriculum among special needs learners in Kenya. Global Journal of Education Research, 19(2). Doi: 10.4314/gjedr.v19i2.2

Ayoti, C., Koteng', G., \& Ongunya, R.O. (2016). Financial Determinants of Instructional materials Management for Enhancing Students' Performance in Secondary Schools in Vihiga County, Kenya. IJRDO-Journal of Applied Management Science, 2(8), 35-56.

Bausch, M. E., \& Ault, M. J. (2008). Assistive technology implementation plan: A tool for improving outcomes. Teaching Exceptional Children, 41(1), 6- 14.

Bosibori, R.O., Ngao, G., Rop, N.K. \& Wesonga, J.N. (2015). Effect of availability of teaching and learning resources on the implementation of inclusive education in pre-school centers in Nyamira North Sub-County, Nyamira County, Kenya. Journal of Education and Practice, 6(35), $132-141$.

Lasoi, J.C., Okoth U. \& Nelson, M. (2017). Board of Managements' Initiatives Influencing Quality Education in Secondary Schools in Kajiado, Kenya. Journal of Education, 1(3), 11 - 25.

Livumbaze, A. G. \& Achoka, S.K. J. (2017). Analysing the Effect of Teaching/Learning Resources on Students' Academic Achievement in Public Secondary Schools, Hamisi SubCounty, Kenya. European Journal of Education Studies, 3(1), $361-376$.
Mabeya, M.T., Gikuhi, M. \& Anyona, N.J. (2019). Influence of working conditions on teacher attrition in public secondary schools in Uasin Gishu County, Kenya. European Journal of Education Studies, 6(5), 87 - 100. https://dx.doi .org/10.5281/zenodo.3366080

Mugure, N. S. (2012). Impact of resource utilization in education as perceived by teachers in secondary schools in Mathioya District, Muranga County, Kenya. Kenyatta University. Kenya.

Mwili, R. K., Tanui, E. \& Ronoh, A. (2015). Influence of instructional materials on secondary school students' academic performance in Makueni County, Kenya. International Journal of Scientific Research and Innovative Technology, 2(15), 70-81.

Njagi, M. S. (2018). Factors influencing Provision of Quality Education in Newly Established Secondary Schools in Mathira Constituency, Kenya (Doctoral dissertation, Karatina University).

Olatunde, P.Y., \& Omondi, K. O. (2010). Teaching/learning resources and academic performance in mathematics in secondary schools in Bondo District of Kenya. Asian Social Science, 6(12), 126- 132. https://dx.doi.org/10. 5430/wje.v6n1p32

Olayinka, A-R.B. (2016). Effects of instructional materials on secondary schools students' academic achievement in social studies in Ekiti State, Nigeria. World Journal of Education, 6(1), $32-39$.

Omego, P.A. \& Simatwa, E.M.W. (2015). Instructional materials-based challenges faced by Principals in enhancing student academic achievement in secondary school education in Kisumu East Sub County, Kenya: An analytical study. Greener Journal of Educational Research, 5(4), 134- 151, http://doi.org/10.1558 0/GJER.2015.4.081615114.

Tety, J. L. (2016). Role of Instructional Materials in Academic Performance in Community Secondary Schools in Rombo

38| This work is licensed under a Creative Commons Attribution 4.0 International License. 
East African Journal of Interdisciplinary Studies, Volume 5, Issue 1, 2022

Article DOI: https://doi.org/10.37284/eajis.5.1.565

District" (Doctoral dissertation, The Open University of Tanzania).

UNICEF (2010). The state of the World Children 2016. Geneva: UNICEF Publications.

Yunusa, U.D. (2016). Educational resources: An integral component for effective school administration in Nigeria. Research on Humanities and Social Sciences, 6(13), 27 - 37.

39| This work is licensed under a Creative Commons Attribution 4.0 International License. 